\title{
円筒シェルの種々の軸圧潰挙動特性とエレベータ緩衝器への応用*
}

\author{
大橋 健 悟*1, 岡 本 紀 明*2, 山泉 洋 平*3
}

\section{Study on Characteristics of Various Collapses of Axially Crushed Tube and Its Application to Elevator Buffer}

\author{
Kengo OHASHI, Noriaki OKAMOTO*4 and Youhei YAMAIZUMI \\ ${ }^{* 4}$ Department of Mechanical Engineering, Shibaura Institute of Technology, \\ 3-9-14 Shibaura, Minato-ku, Tokyo, 108-8548 Japan
}

\begin{abstract}
The final goal of this study is to apply a shock absorber based on plastic deformation of aluminum tube to an elevator buffer. First, in order to study characteristics of axially crushed tubes, various aluminum tubes were compressed on four types of dies. As a result, these caused the three modes of progressive buckling, tearing and inversion. It is concluded that the load-displacement curve of the inversion mode has ideal shape as shock absorber and its inversion load depends on the thickness of the tube. Secondly, energy absorbing mechanism of inversion mode was made clear with finite element method (FEM), and its details show two kinds of energy, frictional dissipation and plastic dissipation produced by meridional bending and circumferential stretching. A theoretical expression for calculation of the inversion load is derived from the virtual work theorem, the prediction from which agrees well both results of experiment and FEM. It is also discrived that use of molybdenum disulfide improves reproducibility of the inversion mode and its load-displacement curve.
\end{abstract}

Key Words : Elevator, Dumper, Plasticity, Inversion, Cylindrical Shell, Axial Crush

\section{1. 緒言}

エレベータには何らかのトラブルが生じた際にも 利用者の安全を確保するために多重の安全装置が取り 付けられている. エレベータ緩衝器は安全システムの 最終段階に位置するものであり，エレベータのかごが 終端部に激突することを防ぐためにピット上に備えつ けられている. 現在この緩衝器にはエレベータの定格 速度に応じて, ばねもしくは油入緩衝器が用いられて いる. ばねは跳ね返りが問題となるために定格速度 $60 \mathrm{~m} / \mathrm{min}$ 以下の低速エレベータに, 油入緩衝器は $60 \mathrm{~m} / \mathrm{min}$ を超える高速エレベータに用いられている(1). 近年, 建築的見地から緩衝器の省スペース化が求めら れるようになり, エレベータ緩衝器ではその長さが問 題となる. また, 省力化の面からメンテナンスフリー 化が求められている.

ところで, 最近は自動車のクラッシャブルストラ クチャに見るように金属の塑性変形を利用した緩衝機 構が注目を集めている. この基礎研究は以前より多方 面から行なわれてきたもの(2)(3)で, 種々の分野にも応 用できるものである. しかし，本研究が対象としてい

* 原稿受付 2004 年 12 月 13 日.

*1 准員, (株) 豊田自動織機 (昰 474-8601 大府市共和町茶屋 8).

*2 正員, 芝浦工業大学工学部(画 108-8548 東京都港区芝浦 39-14).

*3 (株) アマダ (邑 418-0112 富士宮市北山 7020).

E-mail : okamo@sic.shibaura-it.ac.jp
るエレベータ分野に緩衝器として具体的に応用した研 究は, 円筒にフランジを多段に設けた安部らの研究(4) 以外に見当たらないようである.

本研究の最終目標は塑性変形を利用したエレベー 夕用緩衝器の技術開発であるが，本報ではその第一段 としてひずみ速度依存性が鈍感で®，エレベータの実 用範囲では動的効果が小さいことが知られている(4) アルミニウム円筒を用いて静的評価を行なった. 先ず， 種々の異なる境界条件によって軸圧潰変形形態にどの ような違いが現れるかを調べ(の，次にその内で最も エレベータに有用な圧潰挙動であると分った反転塑性 変形に関して有限要素法(FEM)によりエネルギー吸収 のメカニズムを解明した. さらに，その結果に基づき， 設計に必要な最高荷重を算出できる理論式を導くとと もに, エレベータ緩衝器としての適応性に関して検討 を行なったの.

\section{2. エレベータの緩重・機能特性}

2.1 エネルギ一吸収効率エネルギ一吸収性能の 評価にはエネルギ一吸収効率が用いられる(8). エネル ギ一吸収効率 $\eta$ は次の式(1)により定義される.

$$
\eta=\frac{m v^{2} / 2}{m a_{\max } S}
$$


ここで, $m$ は衝突子の質量, $v$ は衝突速度, $a_{\max }$ は最 大加速度, Sは緩衝ストロークである.

エレベータ緩衝器の設計では, 最大加速度 $a_{\text {max }}$ を許 容範囲内に収め, 緩衝ストロークをできるだけ短 くして, エレベータのかごと積載質量の運動エネ ルギーを吸収することが求められる. そのために はエネルギー吸収効率を大きくすればよい.

緩衝器の荷重特性に着目して式(1)を書き換える と式(2)のように表される.

$$
\eta=\frac{F_{\text {avg }}}{\boldsymbol{F}_{\max }}
$$

ここで, $F_{a g}$ はエネルギー吸収の過程における平均荷 重, $F_{\text {max }}$ は最高荷重である.

エネルギー吸収効率を大きくするということは式(2) より平均荷重を最高荷重に近づければよいことを意味 する.

2.2 必要な平均荷重・ストローク エレベータ の安全装置については建築基淮法令(1)(9)によって規定 されている.これによると最大衝突速度は定格速度の 1.4 倍, 平坞减速度は $1 \mathrm{~g}\left(9.8 \mathrm{~m} / \mathrm{s}^{2}\right)$ を超えてはならない とされている.

従って，平均荷重については，質量の最も小さい場 合，すなわち積載質量のないかご質量だけの場合に対 しても，平均减速度が $1 \mathrm{~g}$ 以下となるようにする必要 がある. そのため, 平均荷重 $F_{a g}$ はかごの質量 $m$ 減 速による慣性力と自重の和で与えられる力

$$
F_{\text {avg }}=2 m g
$$

を超えてはならない．

また，緩衝器が吸収しなければならないエネルギ 一Eに関しては, 質量が最も大きい場合，すなわち， かご質量 $m$ と定格積載質量 $m$ 'の合計質量 $M$ の運動工 ネルギーと緩衝ストローク $S$ 分の位置エネルギーの 和である. 平均减速度を $1 \mathrm{~g}$ とすると, $S=v^{2} / 2 g$ が成り立つので，必要な吸収エネルギーEは，

$$
E=\frac{1}{2} M v^{2}+M g S=M v^{2}
$$

さらに, 必要なストローク $S$ は,

$$
\boldsymbol{S}=\frac{\boldsymbol{E}}{\boldsymbol{F}_{\text {avg }}}
$$

\section{の二式でそれぞれ表される.}

典型的なエレベータに対し，これらの式を用いて求
めた緩衝器の設計緒元の例を表 1 に示寸.

Table 1 Shock absorber specification for typical elevator systems

\begin{tabular}{|c||c|c|c|c|c|}
\hline $\begin{array}{c}\text { Elevator } \\
\text { type }\end{array}$ & $\begin{array}{c}\text { Impact } \\
\text { velocity } \\
v(\mathrm{~m} / \mathrm{s})\end{array}$ & $\begin{array}{c}\text { Live } \\
\text { load } \\
m^{\prime}(\mathrm{kg})\end{array}$ & $\begin{array}{c}\text { Elevator } \\
\text { cage } \\
m(\mathrm{~kg})\end{array}$ & $\begin{array}{c}\text { Average } \\
\text { force } \\
F_{\text {avg }}(\mathrm{kN})\end{array}$ & $\begin{array}{c}\text { Stroke } \\
S(\mathrm{~mm})\end{array}$ \\
\hline \hline $\begin{array}{c}\text { Low-speed } \\
\text { Small cage }\end{array}$ & 1.4 & 600 & 750 & 14.7 & 180 \\
\hline $\begin{array}{c}\text { High-speed } \\
\text { Middle cage }\end{array}$ & 2.8 & 1000 & 1250 & 24.5 & 720 \\
\hline
\end{tabular}

\section{3ストローク効率 油入緩衝器では装置の全長} に対して緩衝ストロークは普通 3 割程度(10)であるため 深いピットが必要となる. そのため, 必要な緩衝スト ロークを確保しつつ緩衝器の長さを短くできればピッ トの深さを浅くすることが可能となる.

その指標としてストローク効率らを

$$
\zeta=\frac{s}{L}
$$

で表す。

2.4 信頼性緩衝器はエレベータの安全システム の最終要素であり, 緩衝器として必要な緩衝特性を安 定して発現しなければならない．

\section{3. 種々の軸圧漬変形形態と荷重特性}

3.1 供試体外径 $50 \mathrm{~mm}$, 板厚 $3 \mathrm{~mm}$, 長さ $1100 \mathrm{~mm}$ のアルミニウム押出し円筒より，機械加工を 施し表 2 に示す寸法の円筒シェルを製作し供試体とし た.

供試体の材料はアルミニウム合金A6063 - T5 であ り，引張試験で得られた応力ーひずみ線図を図 1 に示 す. $02 \%$ 耐力は $210 \mathrm{MPa}$ ，引張強さは $240 \mathrm{MPa}$ であ る.

Table 2 Dimensions of specimens

\begin{tabular}{|c|c|c|c|}
\hline $\begin{array}{c}\text { Length } \\
L(\mathrm{~mm})\end{array}$ & $\begin{array}{c}\text { Inner diameter } \\
d_{i}(\mathrm{~mm})\end{array}$ & $\begin{array}{c}\text { Outer diameter } \\
d_{o}(\mathrm{~mm})\end{array}$ & $\begin{array}{c}\text { Thickness } \\
t(\mathrm{~mm})\end{array}$ \\
\hline \hline \multirow{3}{*}{100} & \multirow{3}{*}{46.5} & 47.5 & 0.5 \\
\cline { 3 - 4 } & & 47.8 & 0.65 \\
\cline { 3 - 4 } & & 48.1 & 0.8 \\
\cline { 3 - 4 } & & 48.5 & 1.0 \\
\hline
\end{tabular}

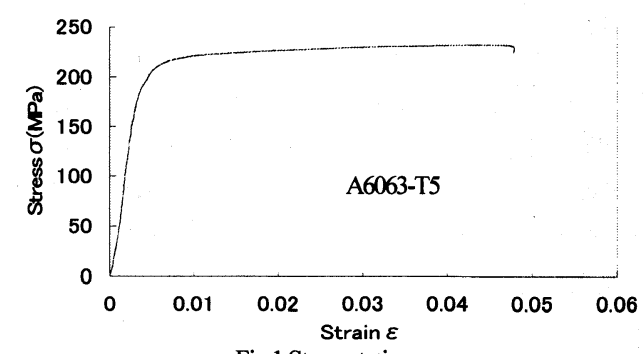

Fig.1 Stress-strain curve 
3.2 実験方法図 2 のように供試体を種々の治具 上に設置し, 万能試験機により, 変位速度 $4 \mathrm{~mm} / \mathrm{min}$ で軸方向一静的に圧縮した. 図 2 - (a)では, 上下平押 し, 図 2 - (b)の内面拘束型では供試体内に上下方向に 可動なピストンを有する上部加圧子と下部の平面加圧 子を用いた. また, 図 2 - (c), (d)では, 上部は平面, 下部は位置決め用突起付の円錐面で圧縮した. 治具と 供試体の接触面にはシリコンオイルを塗布した.

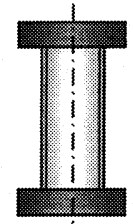

(a) Plané die

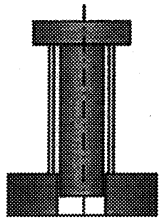

(b) Inner die

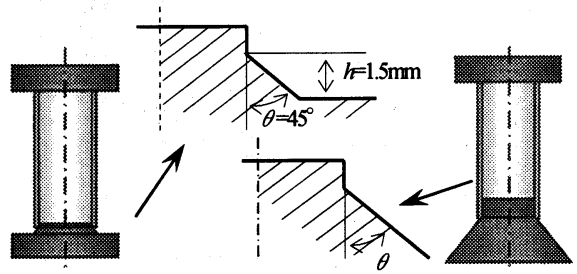

(d) Conical die without step

(c) Conical die with step

Fig.2 Cylindrical shells set on various dies

\section{3 実験結果}

（1）平面型 供試体 4 個とも全て第一座屈におい て高いピーク荷重が生じ, その後連続して座屈が起き た. 図 3 はその一例で板厚 $t=0.5 \mathrm{~mm}$ の場合である.

第二座屈以降の荷重は第一座屈の $50 \%$ に満たない大 きさとなっている. このとき生じる連続座屈の座屈モ 一ドは図中の写真のように非軸対称となった. 座屈モ ードに関しては円筒の半径と板厚の比に支配されるこ とがわかっている(6).

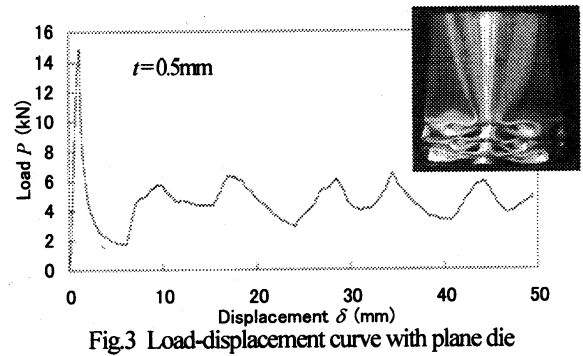

（2）内面拘束型 供試体が板厚 $t=0.5 \mathrm{~mm}$ の場合 の荷重一変位線図と座屈モードを図 4 に示す．供試体 の内側人の変形が拘束されていることにより, 連続座 屈の各リンクルが全て軸対称な形状となった. そのた め, 荷重 - 変位線図には周期的に, ほぼ等しいピーク
が現れた.これにより, 平面型に比べ最高荷重はほぼ 等しいままエネルギ一吸収量を増加させることができ る. 他の板厚の供試体でも同様の現象が確認されてい $ろ^{(7)}$.

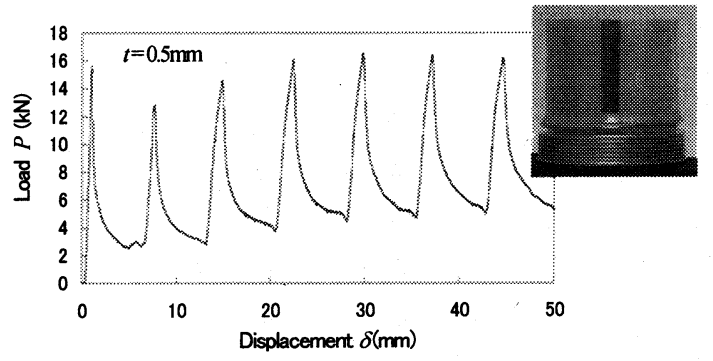

Fig.4 Load-displacement curve with inner die

（3）ステップ付き円錐面型 円錐角 $\theta=45^{\circ}$ の 治具を用いて行なった板厚 $t=0.8 \mathrm{~mm}$ の実験結果を 図 5 - (a)示す.この場合円錐面上を管口が滑ること により円筒の形状が変形し，それが初期不整となって 第一座屈が誘発されたため, 平面型で見られたピーク 荷重が下がったものと考えられる．また，それに続く 第二座屈以降の変形形態は平面型による連続座屈と同 じ座屈モードとなった.

次に板厚 $t=0.5 \mathrm{~mm}$ では, 図 5 - (b)に示すように円 筒の内面が外側に現れる反転塑性変形を示した. この 変形形態では円筒の管口が反転をした後その部分が上

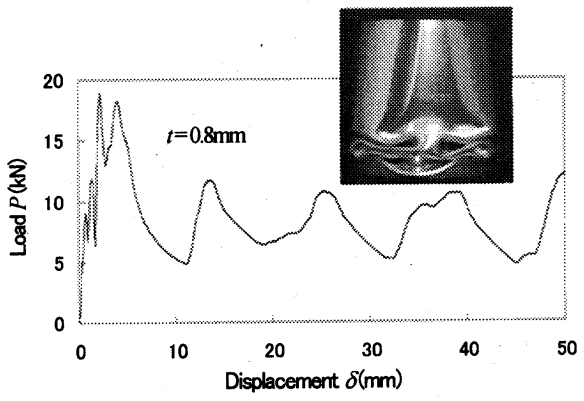

Fig.5-(a) Load-displacement curve by cone angle $45^{\circ}$ die with step

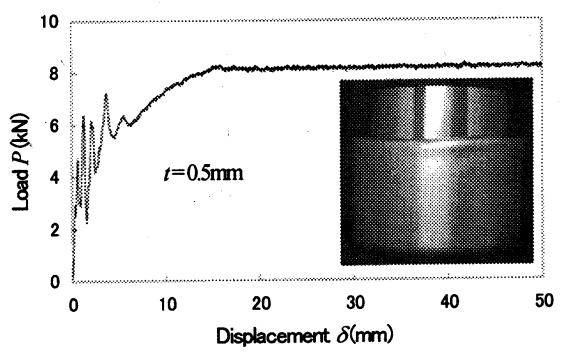

Fig.5-(b) Load-displacement curve by cone angle $45^{\circ}$ die with step 
部に向かって変形が進んだ. 反転後の荷重は一定に保 ったまま安定な状態が得られた. また，この反転時の 荷重が変形過程を通して最高荷重となった.

（4）ステップなし円錐面型前項では円錐面上 を管口が滑るため変形形態が平面型による連続座屈と は異なるものとなった. しかし，円錐角度が大きくな ると滑りが生じなくなるので変形形態は連続座屈とな ると考えられる. また，逆に角度が小さくなれば滑つ て管口を拡げるようになると推測される.

円錐角が $80^{\circ}$ の実験結果を図 6 - (aに示す. この境 界条件では円筒は円錐面を滑り出すことは無かった. 座屈は円錐面に接している下部ではなくその反対の上 部平面側より生じた. 円錐面側では円筒の位置決めの ために内面が拘束されているため, 非軸対称モードで の座屈の発生が抑制されると考えられる. そのため上 部の平面側で非軸対称モードの座屈が発生し, 進展し たと考えられる. したがって, 変形形態, 荷重 - 変位 線図ともに平面型による連続座屈と同じものとなった.

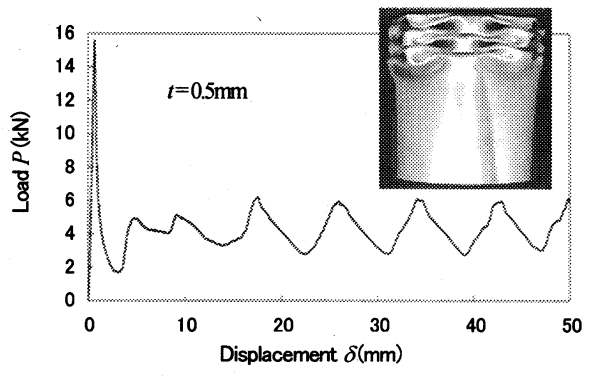

Fig.6-(a) Load-displacement curve by cone angle $80^{\circ}$ die without step

円錐角が $70^{\circ}$ の場合においても同様の現象が観察 された.

円錐角 $30^{\circ} ， 40^{\circ}$ および $50^{\circ}$ の実験結果を図 6 (b)に示す．管口は円錐面上を滑り出し，その部分から 変形を起こした. しかし治具にステップが無いために 円錐面を滑り出した後に反転を起こすことなく, 円錐 面に沿うようにして管がラッパ状に拡げられた. その

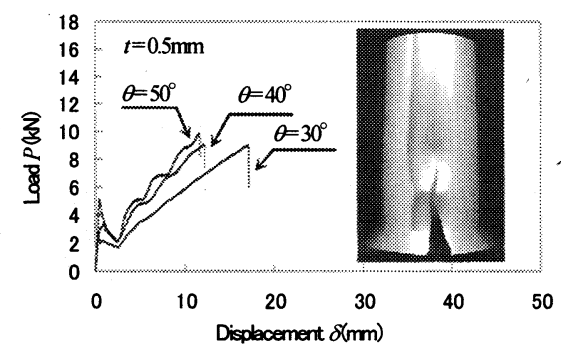

Fig6-(b) Load-displacement curve by cone angle $30^{\circ} \quad 40^{\circ} 50^{\circ}$ die without step
後，拡げられた管口の一籄所より亀裂が生じた. その ため, 十分に軸方向に変位しないまま終わった.

円錐角 $60^{\circ}$ の実験結果を図 6-(c)に示す．管口は円 錐面を滑りだし，ステップが無いにもかかわらず反転 塑性変形を示した. 変形形状や荷重 - 変位線図はステ ップ付き円錐面で得られた反転塑性変形の場合とほぼ 同じであった.

ステップなし円錐面では，変形形態が円錐角の角度 によって異なるものとなった， $30^{\circ} ， 40^{\circ} ， 50^{\circ}$ では 割れが生じ, $60^{\circ}$ では反転塑性変形, $70^{\circ}, 80^{\circ}$ では シェルが円錐面を滑らずに連続座屈となった.

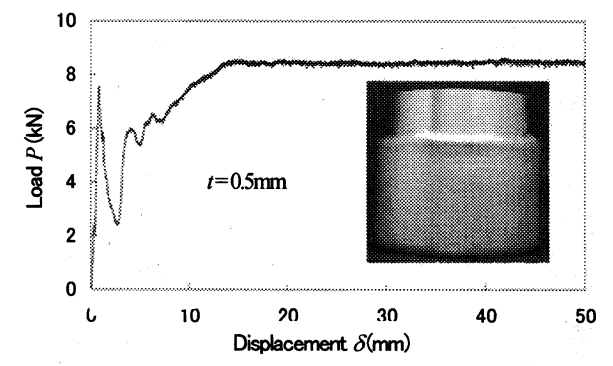

Fig.6-(c) Load-displacement curve by cone angle $60^{\circ}$ die without step

（5）変形形態と吸収効率 変形形態に着目してエ ネルギー吸収効率 $\eta$ を比較するため, 変位 $50 \mathrm{~mm}$ での エネルギー吸収効率を表 3 に示す, 反転塑性変形型で は反転の際に生じる荷重が一定であり, かつその荷重 が変形過程中の最高荷重となっているため $\eta か ゙$ 他の変 形形態に比較して突出して大きくなっている.

Table 3 Energy absorption efficiency of each deformation type at $\delta=50 \mathrm{~mm}$

\begin{tabular}{|c|c|}
\hline Deformation type (Fig. No.) & Energy absorption efficiency \\
\hline Buckling (Fig.3 plane die) & 0.31 \\
\hline Buckling (Fig.4 inner die) & 0.42 \\
\hline $\begin{array}{c}\text { Buckling (Fig.5-a conical die } \\
\text { with step) }\end{array}$ & 0.45 \\
\hline Inversion (Fig.6-c conical die) & 0.91 \\
\hline
\end{tabular}

\section{4. 反転塑性変形型のエネルギ一吸収メカニズムと 機能特性評価}

4.1 エネルギ一吸収メカニスム エネルギー吸収 効率の最も高かった図6 - (c)の反転塑性変形型に関し て変形過程およびエネルギー吸収のメカニズムを解明 するため, 有限要素解析を行なった. 実験での変形形 態が軸対称であったので，モデルは軸対称とした．円 錐面は剛体とし，円筒は 1 次の低減積分軸対称要素を 用いた. 円筒の要素分割は反転を起こす下端から 60 $\mathrm{mm}$ までは軸方向に $0.1 \mathrm{~mm}$ の等間隔，その上部は $1 \mathrm{~mm}$ 間 
隔とした，板厚方向は 2 分割とした. 材料データは図 1 の引張試験曲線を多線分折線近似し等方硬化塑性乇 デルを用いた.アルミ合金はひずみ速度依存性が小さ いのでひずみ速度の効果は考慮していない，摩擦はク 一ロンの摩擦モデルを用い摩擦係数を 3.0 とした. ま た，荷重力法は円筒上部に最大 $50 \mathrm{~mm}$ まで強制変位を 与えた. FEMによる荷重 - 変位曲線と特徵点に対応す る断面形状を図 7 に示す，また，実験後の供試体断面 写真も併せて示す.

(1)から(2)までは円筒の全体が軸圧縮されほぼ均一な 応力が生じる. (2)から(3)では管口が円錐面を滑り, ラ ッパ状に拡がる.このとき端面からおよそ5 nm のとこ ろに曲げが生じる.この曲げられた部分が円錐面より 外に伸び出すことで再び荷重が増加し始める. (3)から (4)では管口が半径方向一拡がり, (4)から(5)で管口が上 方へ向く. (5)から(6)では管口が円筒の中心軸方向へ向 き円筒表面の近くまで進む. ここまでの管口が巻き込 まれる変形形態をカーリングという. (6)以降では, こ れまでに成形されたカール部分が上方へ持ち上がるよ うにして反転が進行する. このときの荷重は一定とな

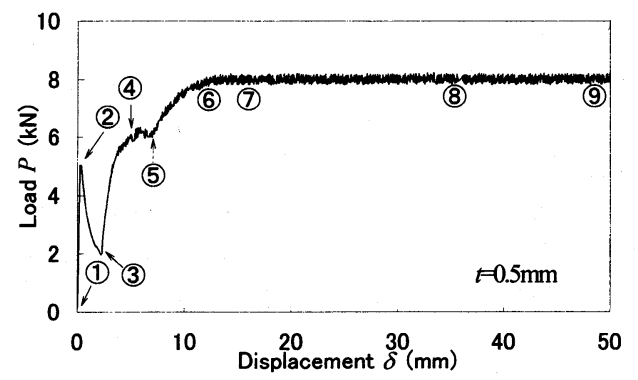

(a) Load-displacement curve

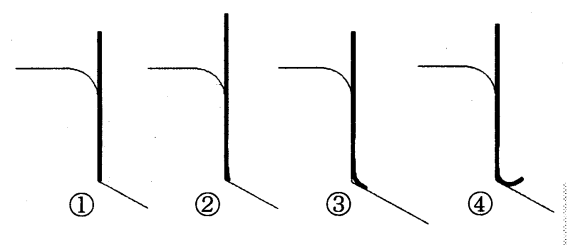

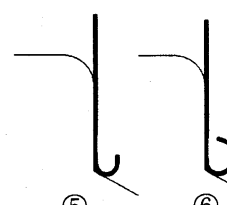

(5)

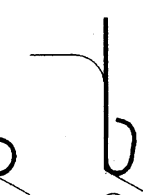

(7)

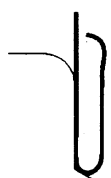

(8)

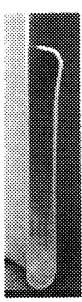

(9) (b) Deformation history

Fig.7 Load-displacement curve and deformation history with cone angle $60^{\circ}$ die by FEM
る. この荷重を反転荷重と呼ぶこととする. 反転後の 形状は実験結果とよく一致している.この変形過程は 実験中にも同様に観察された。

この解析結果を基に変位 $50 \mathrm{~mm}$ までのエネルギ一吸 収量の内訳を表 4 に, 塑性散冕エネルギ一分布を図 8 に示す.

表 4 に示すように荷重による仕事は，そのほとん どが塑性変形と摩擦仕事によって散逸エネルギーと して消費される. 図8より変形した部分では板の中 央面よりも表面に近い部分のエネルギー密度が大き いことがわかる. また，板の中央面でも散逸エネル ギーが現れていることから, 塑性散逸エネルギーは 板の曲げ・曲げ戻し及び円周方向伸びによる塑性変 形によるものであるといえる.

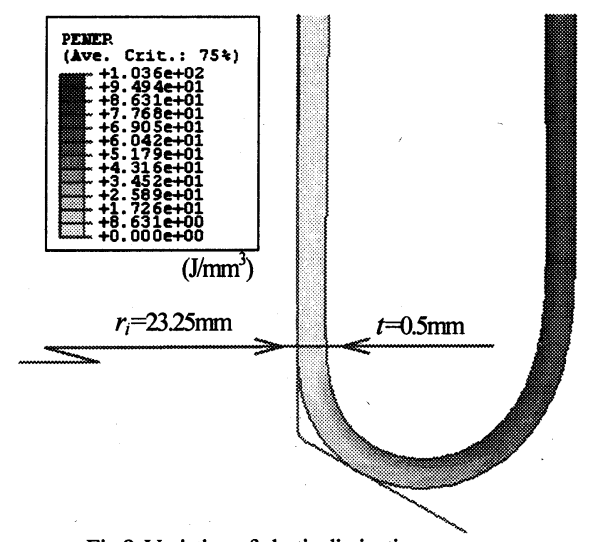

Fig.8 Variation of plastic dissipation energy per unit volume at $\delta=50 \mathrm{~mm}$

Table 4 Details of absorbed energy $(J)$

\begin{tabular}{|l|r|}
\hline Plastic dissipation & 248 \\
\hline Recoverable strain energy & 2.5 \\
\hline Frictional dissipation & 122 \\
\hline External work & 373 \\
\hline
\end{tabular}

\section{2 荷重制御と荷重算定式 ステップなし円錐面} について板厚 $0.5 \mathrm{~mm}, 0.65 \mathrm{~mm}, 0.8 \mathrm{~mm}, 1.0 \mathrm{~mm}$ の四 種類の円筒を用いて圧縮試験を行なった. ここでは, 潤滑剤として二硫化モリブデンを用いた. 各板厚の円 筒は全て反転塑性変形を生じ, 図 9 に示寸荷重 - 変位 線図が得られた. ステップなし円錐面ではステップ部 による干涉が無いために板厚に関係なく反転塑性変形 を生じたと考えられる.

図 9 より板厚が増えるにしたがい反転荷重が増加し ていることがわかる.このことから, 板厚によって最 高荷重を制御することが可能であることがわかる. 
以上のことを踏まえ，反転荷重の算定式を導くこ ととする. いま, 荷重が一定になった状態で, カーリ ング部の曲面が図 10 のように単一の曲率半径 $\rho$ で表さ れるものと仮定する.

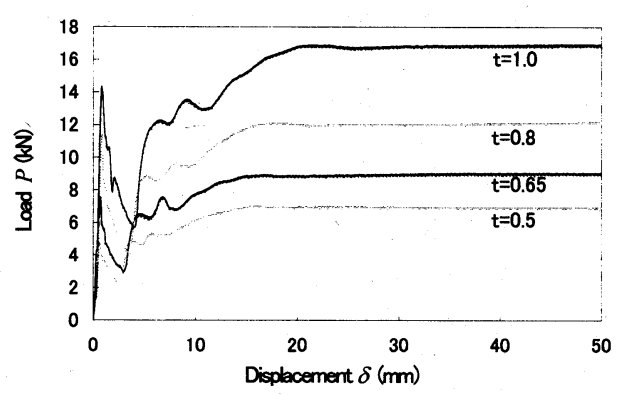

Fig.9 Variation of inversion load as a function of thickness

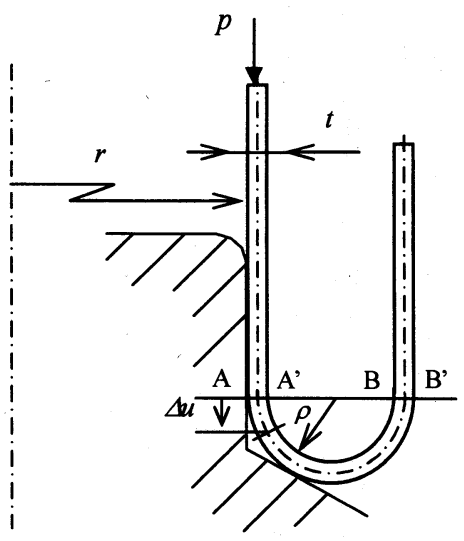

Fig10 Theoretical model of inversion

円周上に垂直方向に表面力 $p$ を受けて $\mathrm{AA}^{\prime}$ 面は $u$ だけ変位するとカール部分では塑性関節が形成され， BB' 面では曲げ戻し変形と円周方向伸びが塑性変形 として生じるものと考える. また, $\mathrm{AA}^{\prime}$ 面から $\mathrm{BB}$ 面への変形過程において板厚の変化はなく, 剛完全塑 性と仮定する.

このとき, 単位面積当たりの外力による仕事は塑性 変形と摩擦の消散エネルギーの和で与えられるので $p t \Delta u=2 \frac{t^{2} \sigma_{Y}}{4 \rho} \Delta u+\frac{2 \rho}{r} \sigma_{Y} t \Delta u+\frac{\mu p t}{\sin \theta+\mu \cos \theta} \Delta u$

と表される. ここで右辺は第 1 項から順に, 曲げ・曲 げ㞍しによる塑性関節, 円周方向伸び, 摩擦のそれぞ れにより消散されるエネルギーである. また, $r$ は円 筒の半径, $t$ は板厚, $\sigma_{\mathrm{Y}}$ は降伏応力, $\theta$ は円錐面の円 錐角, $\mu$ は摩擦係数である. また, $\rho$ はカーリング半
径であり, 円筒の直径を $d$ とすると北澤らによる文献 (11)より式(7)で表される.

$$
\rho=\sqrt{\frac{t d}{8(1-\cos \theta)}}
$$

$p$ は単位面積当たりの表面力であるから, 円筒の反 転荷重 $P$ は次式より求められる.

$$
P=2 \pi r t p
$$

式(6)をpについて整理し，式(8)に代入すると

$$
P=\frac{\pi d t \sigma_{Y}}{1-\mu /(\sin \theta+\mu \cos \theta)}\left[\frac{t}{2 \rho}+\frac{4 \rho}{d}\right]
$$

となり,これが反転荷重の理論近似式となる.

次に実験結果及び FEM 解析結果と理論式を比較す る. 材料特性值として, 理論式の $\sigma_{Y}$ には $0.2 \%$ 耐力 210MPa を用い, FEM の応力 - ひずみ関係には図 1 の引張式験結果を多線分近似した材料モデルを用いた。 摩擦係数は FEM，理論式ともに二硫化モリブデン潤 滑として 0.1 とした. これらの結果を図 11 に示す. 実験結果と FEM の結果はよく一致している. 理論式 は多少小さめに見積られているが，この原因は完全塑 性体を仮定しているためである. FEM での反転部に は $0.2 \%$ 耐力以上の応力が生じており, 加工硬化によ る応力の上昇を考慮すれば理論式の解も実験結果及び FEM の結果に近くなると考えられる. 式(9)により反 転荷重の見当をつけることが可能であり, 設計に際し て式(9)を用いることで最大緩衝力が概算できる.

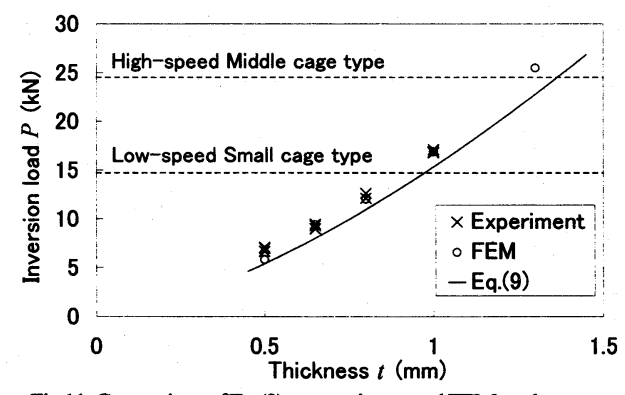

Fig.11 Comparison of Eq.(9) to experiment and FEM, and average buffer load demanded for typical elevators

表 1 で示したエレベータの種類に対する所要荷重を 図 11 で見ると, 小型低速のエレベータには実験で用 いた形状寸法で十分に緩衝器の仕様を満足している. また, 高速中型タイプでは式(9)より板厚が $1.4 \mathrm{~mm}$ 程 度の円筒で満足できることがわかる.

4.3 ストローク効率 反転塑性変形型では変形し た管口が上方へ向かうため，緩衝ストロークは円筒の 
全長の $50 \%$ 以上を確保できる. これは油入緩衝器よ りも向上しており, 省スペース化につながる.

4.4 信頼性丹錐面と円筒との潤滑にシリコンオ イルを用いてステップなし円錐面の実験を 3 回行なつ たところ, 全て反転塑性変形を生じたが同じ荷重経路 をとらないものや変形の途中で座屈を起こすものがあ った. その荷重 - 変位線図を図 12-(aに示す. この 原因は，流動性の高いシリコンオイルが円錐面上を流 れ出たこと，円筒と円錐面の高荷重下における摩擦に より油膜が切れたためであると考えられる.

そこで, 油膜切れを防ぐためにペースト状の二硫化 モリブデンを潤滑剤として用いることとした. 二硫化 モリブデン潤滑での実験結果を図 12 - (b)に示す。潤 滑を二硫化モリブデンとしたことで, 3 回とも同じ変 形形態を得ることができ, 荷重 - 変位線図も再現性の あるものとなった. また, 他の板厚の円筒についても 再現性は板厚 $0.5 \mathrm{~mm}$ のものと同様にほぼ同一の変形 形態と荷重一変位線図が得られた. 二硫化モリブデン 潤滑で緩衝器に必要な信頼性が得られることが分った.

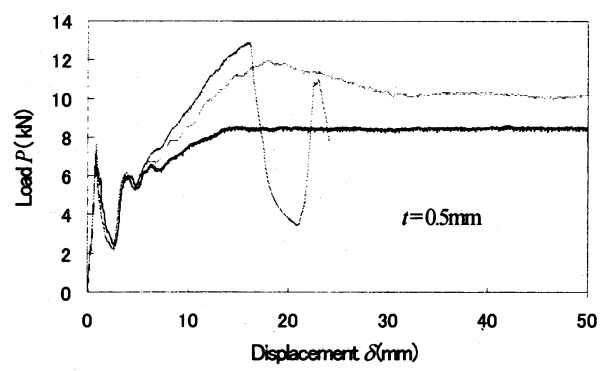

(a) Silicone oil lubrication

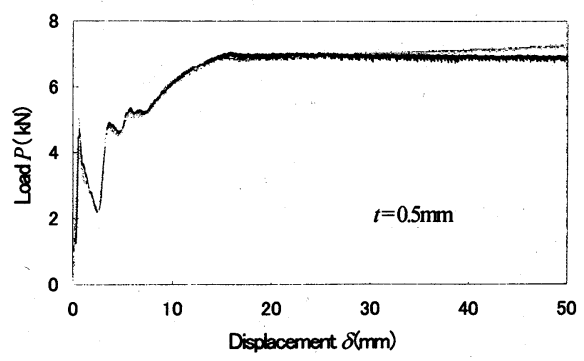

(b) Molybdenum disulfide lubrication

Fig.12 Effect of lubricant on load-displacement curve

\section{5. 結 言}

得られた主な知見を示すと下記の通りである.

（1）境界条件の違いによって引き起こされる様々な変 形形態に対してエネルギ一吸収効率を比較したと ころ, 反転塑性変形型はエネルギー吸収効率が
90\%以上で突出して良い. そのため, エレベータ 緩衝器として最も適した荷重 - 変位関係を得るこ とができる.

（2）下支え治具の円錐面をステップの無い円錐角 $60^{\circ}$ とすることで板厚に影響されることなく反転 塑性変形が安定して得られ, 円筒の板厚により荷 重制御が可能である.

（3）最高荷重である反転荷重を算定する理論式を仮想 仕事の原理より誘導し, 設計式として提案した.

（4）理論式より緩衝荷重が推定できるためエレベータ 緩衝器の円筒シェルの形状寸法を設計できる.

（5） 円錐面治具と円筒との潤滑に二硫化モリブデンを 用いることで安定した信頼性の高い荷重 - 変位曲 線が得られる.

（6） 反転塑性変形型ではストローク効率は最低 $50 \%$ は確保できる.

\section{文献}

(1) 平成十二年建設省告示第千四百二十三号

(2) N.Jones, Structural Impact, (1989), 385, Cambridge University Press

(3) S.R.Reid, Plastic deformation mechanisms in axially compressed metal tubes used as impact energy absorbers, Int. J. Mech. Sci., 35-12 (1993), 10351052

（4）安部貴・宮田弘市・重田 政之・大亦絢一郎・ 納富 充雄 ・伊東菜摘, 機構論, No.02-56, (2003-1), 9 12

（5）大橋健悟 - 岡本 紀明 - 山泉 洋平, 機構論, No.0457, (2005-1), 7-10

(6) 山泉洋平 - 岡本紀明 - 大橋健悟 - 新堀 充弘, 機構 論, No.02-1, (2002-9), 69-70

(7) 山泉洋平 - 岡本紀明 - 大橋健悟, 機構論, No.0301, (2003-3), 215-216

(8) Cyril M. Harris - Allan G. Piersol, Harris'Shock and Vibration Hand Book fifth edition, (2002), 31.6, McGraw-Hill

（9）オーム社編，2003 年度版建築基淮法令集，(2002）２44， オーム社

(10) 岡本正勝 - 中川俊明 - 海田 勇一郎 - 関本陽 - 藤 田 善昭, 機構論, No.02-56, (2003-1), 17-20

（11）北澤君義 - 小林勝, 塑性と加工, 28-323(1987), $1267-1274$ 